http://journals.ums.ac.id/index.php/ijolae

\title{
The Politeness Comments on The Indonesian President Jokowi Instagram Official Account Viewed From Politico Pragmatics and The Character Education Orientation in The Disruption Era
}

\author{
Harun Joko Prayitno ${ }^{1}$, Hari Kusmanto ${ }^{2}$, Yakub Nasucha ${ }^{3}$, Laili Etika Rahmawati ${ }^{4}$, \\ Norliza Jamaluddin ${ }^{5}$, Samsuddin 6 , Awla Akbar Ilma ${ }^{7}$ \\ ${ }^{1,2,3,4}$ Faculty of Teacher Training and Education, Universitas Muhammadiyah Surakarta, In- \\ donesia \\ ${ }^{5}$ Faculty of Language and Communication, UPSI, Malaysia \\ ${ }^{6}$ Faculty of Social and Humanitarian, UPSI, Malaysia \\ ${ }^{7}$ Faculty of Arts and Humanitiez, Suez Canal University, Egypt
}

DOI: 10.23917/ijolae.v1i2.8785

Received: September $7^{\text {th }}, 2019$. Revised: September $25^{\text {th }}, 2019$. Accepted: September $30^{\text {th }}, 2019$ Available Online: September $30^{\text {th }}, 2019$. Published Regulary: Juli $1^{\text {st }}, 2019$

\begin{abstract}
Politeness of expression and character education are both crucial aspects and related to Indonesian education. In the context of communication where the advancement of the internet and technology has now made communication without limit, a new problem arises. The social media, e.g. Instagram, gives space to their users to be more open in expressing his ideas and political opinions. This study aims to identify the forms of positive politeness acts of followers' comments on President Jokowi's official Instagram account and describe the intent of politico pragmatic power of positive politeness of followers of Jokowi's Instagram accounts. The data source of this study was the speech of followers on the official Instagram account of Indonesian President Jokowi \#MenujuIndonesiaMaju managed by the President's Digital Communication Team for the period October-November 2018. The study data were in the form of comments from Jokowi's Instagram account followers who had positive politico pragmatic politeness. The data collection technique was carried out using documentation, note-taking techniques, and continued with heuristic listening techniques. Data analysis was performed with an intralingual equivalent technique which was strengthened by an extra lingual equivalent and sharpened with Levinson's politeness analysis technique based on the principle of harmony in Javanese culture. The results of the study showed that the form of positive politeness acts that were most used by followers was by giving attention to the speech partners. Political propaganda power of dominant followers' comments was in the form of the power to ask and support rather than the power of praise, the power of influence, the power of motivation, and the power of suggestion. It shows that Instagram account followers have an optimistic attitude towards Jokowi's leadership. Jokowi's managerial, and leadership performance has a positive face among followers. The ability to praise, motivate, and advise is an essential component in the formation of children's character education in the disruptive era in education.
\end{abstract}

Keywords: political comments, positive politeness, language act, character education, disruption era. Corresponding Author: Harun Joko Prayitno, Faculty of Teacher Training and Education, Universitas Muhammadiyah Surakarta, Indonesia, email: harun.prayitno@ums.ac.id 


\section{Introduction}

Politeness in language act needs special attention from and given examples by teachers, lecturers, and the community in general. Politeness is not only related to language; politeness is also related to politics (politeness in politics). If the politeness matter is watched out for, it is not impossible, and there will be a shift and even a deficit.

Politeness matter of language usage at this time is very terrible. It is seen based on some previous research findings which state that there has been a use of impolite language. The following forms of impoliteness in language: ridicule and use of harsh words (Mansor et al. 2014); direct criticism, spread hatred, and attack the personality of others (Kusno \& Rahman, 2016); shifts and deficits in the politeness of language usage in students (Noor \& Prayitno, 2016); and the use of dysphemia on social media (Ulum \& Kusmanto, 2018).

The country's official Instagram account, Jokowi, is one of the social media accounts that have the most followers. Jokowi's Instagram account has 17.7 million followers. The politeness strategy dialectics in commenting on Jokowi's Instagram account is interesting to be studied. How the politeness strategy used by followers in commenting is interesting to study the positive politeness values and the formation of children's character education. Children's character education is an important aspect in the development of a nation (Aisyah, 2014; Koussouhon \& Dossoumou, 2015; Zurqoni, Retnawati, Apino, \& Anazifa, 2019).

Acts of politeness in the language is a communication behavior that must pay attention to ethics. Ethics or manners in communication must connect power and meaning (Kusno dan Rahman, 2016). Speech participants' compliance with communication ethics can make harmonious speech relations or run smoothly. It is as stated by Tamrin (2014) politeness is an effective communication strategy to avoid conflict between individuals in a communication.

Positive politeness acts can be realized in several forms. Brown and Levinson (in Fauziati, 2016) mentions that there are fifteen positive forms of politeness which include: (1) paying attention to the wishes, likes, and needs of the speech partner; (2) giving attention; approval, and sympathy of speech partners; (3) intensifying the attention of the speaker by dramatizing events and facts; (4) using identity markers; (5) seeking approval; (6) avoiding disagreements with the speech partner; (7) shows similarities with speech partners (8) using jokes in communication; (9) shows understanding with speech partners when communicating; (10) showing an optimistic attitude; (11) involving speech partners in speech activities; (12) asking questions or asking for reasons; (13) offering or promising; (14) stating reciprocal relations; and (15) giving a gift.

Politeness, according to Brown and Levinson (in Leech, 2014) is an effort to keep the face of the other person. It means that more speakers appreciate the speech partner the more it shows her polite personality (Fitriani, 2015). An act of politeness in communication is not only seen from the selection of diction. It means that the context of a speech in communication plays an essential role in understanding language (Sukarno, 2015). There are several aspects determine an act of communication which can be said politely, namely age, social distance, situation, time, place, and purpose in communication acts (Jahdiah, 2018; Najeeb, Maros, \& Nor, 2012; H. K. Tan, Teoh, \& Tan, 2016).

Politico pragmatic power is the meaning that is implied behind an utterance, which 
can move someone to do something that is meant in the implied meaning. Yuliana et al. (2013) state power include meaning and semantically, power at the same time can be derived from meaning. Politico pragmatic power cannot be interpreted based on the rules of grammar but through the principle of cooperation. Through the study of the principle of cooperation, a new interpretation was found which obeys the principle of cooperation and thus is referred to as a politico pragmatic power.

The use of language is essentially a representation of the personality of the speaker. As stated by Leech (2014) assumes that meaning can be portrayed through semantic representation in a language, whereas power is given through implicature. Furthermore, indirect illocutionary power is sufficiently expressed through implicature. Implicatures are statements that refer to the speaker's mental state. In simple terms, it can be said that politico pragmatic power is the intention to be conveyed by speakers of a language.

Pragmatic studies and political discourse have been separated so far, so there is a need for integration called politico pragmatic studies. Politico pragmatic study is the study of language in political discourse. It is as stated by Prayitno (2015) linguistic studies that base on political messages to be used as political studies through politico pragmatics. It shows that pragmatic studies have explored indefinitely in the communication and computing industry 4.0 era at this time (Prayitno et al. 2018). The phenomenon of language use containing politico pragmatic intent on Instagram accounts which has now become an inseparable part of the child's living environment is an important issue in the formation of children's character education in schools.

The problem is how the realization of positive politeness in the formation of chil- dren's character education is still in the process of growth and development in the era of disruption of education as it is today. An era of global computing that the aspects, processes, and outcomes of education are changing very quickly. Therefore, the results and discussion of this study would focus on how a positive politeness manifestation of followers comments on Jokowi's Instagram account; and how the politico pragmatics power of the positive politeness comments of Jokowi's Instagram account followers in the perspective of identity formation and character education of children in the era of disruption of education.

\section{Method}

The main approach developed in this study is in the form of qualitative (Tojo \& Takagi, 2017; Zurqoni et al., 2019). The qualitative approach in this study is to produce a theoretical generalization in the political comments on Jokowi's Instagram account. By following the qualitative study method used in this study, the data in this study were in the form of comments that have a politeness value on Jokowi's Instagram account. The data source in this study was in the form of followers' comments in Jokowi's Instagram account from October to November 2018. Language use became an important contribution to the successful campaign in the Indonesian presidential election in the 2019-2024 period. The collection technique was done by using the documentation method and referred to the note-taking technique. The document referred to in this study was in the form of Jokowi's Instagram account followers' comments. The method in this study was done by scrutinizing, which was scrutinized to the comments on Jokowi's Instagram account followers' comments. Furthermore, after the data were obtained through 
listening, the data were recorded on the data card according to the politeness strategy of commenting. The data analysis technique in this study used the intralingual equivalent method which was strengthened by the extra lingual equivalent technique (Cisco, 2016; Mahsun, 2014). The intralingual equivalent method in this study was used to identify the politeness strategy of commenting on Jokowi's Instagram account. The extra lingual equivalent method in this study was done by identifying the politeness of politeness and positive politeness contained in Jokowi's Instagram account comments in the perspective of harmony in Javanese culture. (Harun Joko Prayitno, Ngalim, Sutopo, Rohmadi, \& Yuniawan, 2018; H. K. Tan et al., 2016).

\section{Result and Discussion}

The results and discussion of the following studies would focus on the embodiment of positive politeness acts of followers' comments on Jokowi's Instagram account and the intention of politico-pragmatic power of positive politeness of followers' comments on Jokowi's Instagram account on the perspective of identity formation and children's character education in the era of educational disruption.

\section{Form of Positive Politeness}

The positive politeness forms used by Jokowi's Instagram followers can be grouped into seven forms. The seven forms are (a) giving attention and sympathy; (b) showing optimism; (c) using identity tags; (d) asking questions (e) involving speakers in speech activities; (f) making promises; and (g) using jokes. The realization of a positive form of politeness, giving attention to leaders from the community to leaders is one of the best ways of political communication. This finding shows that the form of attention is not only from the leader to people, but also to embrace the two parties between the leader and people (Adams, 2009; Darwis, Sciences, \& Sumatra, 2013; Singh \& Chakrabarti, 2017). This finding is illustrated in Figure 1.

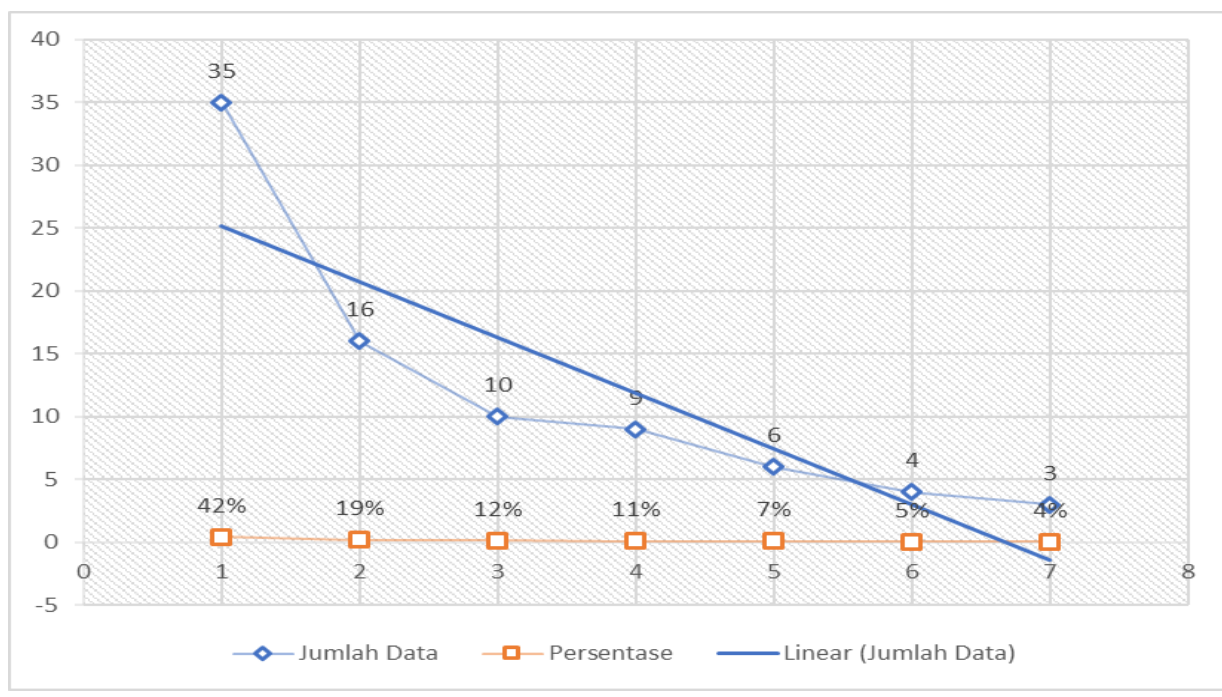

Explanation:

1. give attention

2. show optimism

3. use an identity marker

4. asking questions
5. involving speakers in speech activities

6. give promises

7. use jokes

Figure 1. Embodiment of Positive Politeness Acts of Jokowi’s Instagram Followers 


\section{a. Giving Attention to Speech Partners}

One of the objectives of communication can be achieved if the speaker and the speech partner give attention to one another. Giving attention to the speech partner is as a form of positive politeness. Abbas (2013) expressed positive politeness aimed at building friendly and harmonious relationships with speech partners. Ways to pay attention to the MT (speech partner) are a polite way of communicating (Ahmed \& Maros, 2017; Kusno \& Rahman, 2016). The following is a line of comments in Jokowi's Instagram account in giving attention to the speech partner.

Table 1. Politeness of Giving Attention to Speech Partners

\begin{tabular}{lllll}
\hline \multicolumn{2}{c}{ Form } & \multicolumn{2}{c}{ Context } & Meaning \\
\hline [1] & $\begin{array}{l}\text { Pak Jokowi semoga menang, } \\
\text { semoga semakin bisa memimpin }\end{array}$ & Jokowi posted a post regarding & Giving attention & to \\
negara, sehat selalu pak & Para Games, at the Bung Karno \\
(seliindira.g29_, 7-10-2018) & Main Stadium with Bulan and & \\
archery athlete Abdul Hamid. & \\
Mr. Jokowi may win; hopefully & & \\
he can lead the country, always \\
healthy, Sir. \\
(seliindira.g29_, 7-10-2018)
\end{tabular}

Speech in data (1) is a political discourse of leadership. The above statement was delivered by the owner of the Instagram account seliindira.g29_ on Jokowi's post regarding the opening of the 2018 Asian Para Games, at the Bung Karno Main Stadium with Bulan and archery athlete Abdul Hamid. Speech Pak Jokowi semoga menang, semoga semakin bisa memimpin negara, sehat selalu pak (Mr. Jokowi may win, hopefully, he can lead this country, always healthy, Sir) is a form of attention to Jokowi. It is as stated by Yayuk (2016) over-attention to speech partners as a politeness strategy saved the face of speech partners in the context of this study is Jokowi.

Acts of politeness in political communication are important to build good leadership; besides that, good political communication is one of the success factors in leadership. It is as stated by (Öztürk, Varoğlu, \& Varoğlu, 2017; Prasetyo, 2014) that in order to achieve common goals between leaders and the community, good political commu- nication is needed between the leaders and the people they lead.

\section{b. Demonstrating Optimism}

The form of positive politeness is then carried out by showing confidence or optimism to the speech partner. The speech partner in communication is happier with an optimistic person than a pessimist. The following comment on Jokowi's Instagram account shows an optimistic attitude.

The data narrative (2) below is a political economic discourse. The owner delivers the utterances of the puspita5296 Instagram account who commented on Jokowi's post. Through speech Baru presiden yang ini, memintarkan rakyat (Not until the current president, makes people smarter) shows an optimistic attitude to the stability of prices of staples and food.

Economic communication is an important thing for the development of economic activities such as the industry. A person working in the field of economics and business must have good communication 
competencies; it is to support his success in the economic and business fields. It is as stated by Darwis et al. (2013). In the business world, good communication, besides having good communication skills (of course), must also use various types of communication tools or media available to deliver business messages to other parties in an effective and efficient way.

Table 2. Politeness of Demonstrating Optimism

\begin{tabular}{|c|c|c|c|}
\hline & Form & Context & Meaning \\
\hline [2] & $\begin{array}{l}\text { Baru presiden yang ini, } \\
\text { memintarkan rakyat. } \\
\text { (puspita5296, 19-10-2018) } \\
\text { Not until the current president } \\
\text { smarting the people. } \\
\text { (puspita5296, 19-10-2018) }\end{array}$ & $\begin{array}{l}\text { Jokowi posted an activity every } \\
\text { morning, which was monitoring } \\
\text { the development of prices of } \\
\text { staples and food. }\end{array}$ & $\begin{array}{l}\text { Show optimism to } \\
\text { speech partner }\end{array}$ \\
\hline
\end{tabular}

c. Using Greeting Identity Markers to Pray

The realization of positive politeness acts can be done by using identity markers. It is as stated by H.K et al. (2014) group identity markers are used in communication to build solidarity. The identity markers referred to in this study are in the form of greetings, dialects, jargon, or slang. Following are comments in Jokowi's Instagram account that uses identity markers.

Table 3. Politeness of Using Greeting Identity Markers to Pray

\begin{tabular}{llll}
\hline & \multicolumn{2}{c}{ Context } & Meaning \\
\hline [3] & \multicolumn{1}{c}{ Maju lagi pakdheku Jokowi } & Jokowi posted a post regarding & Utilizing identity and \\
saya selalu mendoakan bapak & the opening of the 2018 Asian prayer for speech partner \\
(renahhappy78_11-10-2018)” & Para Games, at the Bung Karno & \\
& Main Stadium with Bulan and & \\
Going forward again my uncle & archery athlete Abdul Hamid. & \\
Jokowi, I always pray for you &
\end{tabular}

(renahhappy78_11-10-2018)

The data narration (3) above is a political discourse of leadership. The utterances are spoken by the renahhappy Instagram account user. The comment was given on Jokowi's post regarding the opening of the 2018 Asian Para Games. Political communication of leadership became important to shape Jokowi's image. Leiliyanti et al. (2017) state that Jokowi's imaging model is community-oriented, which always updates its face with personal characteristics, is not centralized, and uses our pronouns, and places the public as active participants.
Pakdheku (my uncle) in Indonesian means uncle. The use of the word aims to show the closeness between the speaker and the speech partner. It is as stated Jauhari dan Susanto (2014) that the use of identity markers functions to express positive politeness. In addition, the use of the word pakdheku can show politeness in language and shows a good relationship between Jokowi and his people. It is as stated by Sukarno (2018) that the purpose of the politeness act in a language is basically to save or protect the face, which in turn can produce good communica- 
tion between the speaker and the speech partner.

\section{d. Giving Questions to Convince}

Giving questions to the speech partners in communication is as a form of positive politeness. It is as stated by Maros dan Rosli (2017) that giving questions to the speech partner is as a strategy to avoid disputes and shows friendliness. Through these questions, they show that the speech partners pay attention to the topics presented by the speaker. Following are comments in Jokowi's Instagram account that has a positive politeness value by asking questions.

Table 4. Politeness of Giving Questions to Convince

\begin{tabular}{llll}
\hline \multicolumn{2}{c}{ Form } & \multicolumn{1}{c}{ Context } & Meaning \\
\hline [4] $\begin{array}{l}\text { Gimana pak masalah banser } \\
\text { yang membakar bendera } \\
\text { tauhid"? }\end{array}$ & $\begin{array}{l}\text { his activities in Vastenburg Fort convince speech partner } \\
\text { (Indraprasethio, 22-10-2018)" }\end{array}$ & $\begin{array}{l}\text { Solo to commemorate the Santri } \\
\text { (religious person, students of }\end{array}$ \\
How is the problem with the & $\begin{array}{l}\text { Islam) Day as a form of respect, } \\
\text { appreciation, and gratitude for }\end{array}$ \\
banser who burns the & $\begin{array}{l}\text { and } \\
\text { monotheism flag, Sir? }\end{array}$
\end{tabular}

(Indraprasethio, 22-10-2018)”

Speech in data (4) above is a religiouspolitical discourse. The speech was delivered by the owner of the Indraprasethio Instagram account to ask about the case of burning the monotheism flag. Speech Gimana pak masalah banser yang membakar bendera tauhid (How is the problem with the banser who burned the monotheism flag, Sir?) shows a form of positive politeness, through these questions. It shows the speaker is paying attention to what the partner said. Religious politics is vital to increase public trust. Abdullah (2017) states the use of the internet as a medium of religious communication is a sign of the importance of communication. The implication in the public sphere is to change public awareness of the relationship of religion with humans and to place religion as an object of questionable validity. Building the image of religious institutions needs polite communication, both polite and religious.

\section{e. Involving the speech partner in the victory prayer activity}

Involving speakers and speech partners in speech activities is a form of positive politeness. The involvement of the speech partners in the act of communication can be done by using markers as we say. (Jauhari, 2018) states that the use of our words in the act of communication has an effect or politeness. Following are comments in Jokowi's Instagram account involving speech partners in communication.

The data narration (5) below is a healthy political discourse. The speech was delivered by the owner of the Instagram account didijournal who commented on Jokowi's post. The use of the word Kita (We) in data (5) is a form of positive politeness by involving speech partners in communication activities.

Courtesy action in the health sector is important for the success of health programs. It is as expressed by Riauan dan Shasrini (2017) one of the supporting factors that can improve the image of health services is therapeutic communication. Setijowati (2018) Indonesian people, especially women who 
experience the most health cases, but they information relating to health. One of them is are far from the information. Therefore, it is by using polite language. necessary to have a strategy in presenting

Table 5. Politeness of Involving the speech partner in the victory prayer activity

\begin{tabular}{|c|c|c|c|}
\hline & Form & Context & Meaning \\
\hline [5] & $\begin{array}{l}\text { Jaga kesehatan ya pak, dan kita } \\
\text { sebagai rakyat Indonesia, tak } \\
\text { henti mendoakan korban gempa } \\
\text { dan Indonesia, dan tak lupa kami } \\
\text { menyelipkan doa agar bapak } \\
\text { diberikan kesehatan dan kekuatan. } \\
\text { (didijournal, 19-10-2018) } \\
\text { Take care of your health, sir, and } \\
\text { we as the people of Indonesia, } \\
\text { endlessly pray for the victims of } \\
\text { the earthquake and Indonesia, and } \\
\text { do not forget we put in a prayer for } \\
\text { your health and strength. }\end{array}$ & $\begin{array}{l}\text { Jokowi uploaded his meeting } \\
\text { with world leaders in Bali, one } \\
\text { of whom was the UN secretary- } \\
\text { general Antonio Gutteres. }\end{array}$ & $\begin{array}{l}\text { Involving speech partner } \\
\text { in prayer for victory }\end{array}$ \\
\hline
\end{tabular}

\section{f. Giving Promises to the Leadership Victory}

Communication that has certainty makes the speech partner feel satisfied. Satisfaction is because communication goals can be achieved. Aziz (2017) discloses that the agreement strategy helps to maintain harmo- ny and increases solidarity with the speech partners. One form of positive politeness is by giving a promise of certainty to the speech partners. Following is a comment on Jokowi's Instagram account that gives promises.

Table 6. Politeness of Giving Promises to the Leadership Victory

\begin{tabular}{llllll}
\hline \multicolumn{4}{c}{ Context } & Meaning \\
\hline [6] "Kami pilih nomor 1 saja & Jokowi uploaded a post Giving a promise for \\
Jokowi-Ma'ruf Amin untuk & $\begin{array}{l}\text { regarding the anniversary of the leadership victory } \\
\text { Indonesia maju” } \\
\text { (wawan_jiswan1, 20-11-2018) }\end{array}$ & $\begin{array}{l}\text { Prophet Muhammad's birthday } \\
\text { at the Bogor Palace. }\end{array}$ \\
"We choose number 1 Jokowi- & & \\
Ma'ruf Amin for the advance- \\
ment of Indonesia"
\end{tabular}

The data narration (6) above is a religious-political discourse. The comment was given by the owner of the Instagram account wawan_jiswan1 on Jokowi's post. Speech Kami pilih nomor 1 saja Jokowi-Ma'ruf Amin untuk Indonesia maju (We choose number 1 Jokowi-Ma'ruf Amin for the advancement of Indonesia) included a form of positive politeness because the speaker gives a promise to the speech partner that the speaker will choose Mr. Jokowi and Ma'ruf Amin in the 2019 presidential election.

The religious-political discourse in the data above relates to the celebration of religious holidays, namely the birthday of the Prophet Muhammad. Commemoration of religious holidays is often used by politicians to communicate with speech partners. It is as 
stated by Rachmiatie et al. (2019) that religious events and commemorative holidays are often used as a place to communicate with constituents.

\section{g. Using a Joke for the leadership victo- ry}

The use of jokes or humor in communication is indeed necessary, because through jokes often makes the speech partner feel happy. It is consistent with the statement of Dynel (2016) in general the form of humor in a conversation saves a positive face. The realization of humor in commenting on Jokowi's Instagram account was also carried out. The following is a remark on Jokowi's Instagram account comments using humor.
The speech in data (7) below is a political discourse of leadership. The comment was given by the owner of the Instagram account 13_calviendr_reiky on Jokowi's post about being together with Mr. Sutopo at the Bogor Palace. The utterances in the above data are comments in the form of leadership political humor. The use of humor in the data above is as a strategy to establish solidarity with speech partners. It is as stated by Herniti et al. (2016) humor in pragmatics is allowed because humor signifies intimacy and serves to break the ice in political communication. Furthermore, Dynel dan Poppi (2019) states the main purpose of humor is to create entertainment.

Table 7. Politeness of Using a Joke for the leadership victory

\begin{tabular}{lll}
\hline \multicolumn{1}{c}{ Form } & \multicolumn{1}{c}{ Context } & Meaning \\
\hline "Potong bebek Angsa: & Jokowi uploaded his & Make of jokes for \\
Potong bebek angsa & logether with Mr. Sutopo & \\
Masak di kuali & who came at Bogor Palace. & \\
Bikin maju bangsa & & \\
Harus dua kali & & \\
Dukung Jokowi & & \\
For 2 kali & & \\
Tralalalalalala & & \\
Jokowi capres & & \\
Amin cawapres & & \\
Tralalalalalalala \\
(13_calviendra_reiky, 12-10- \\
2018)" \\
"Cut the Goose Duck: \\
Cut the goose duck \\
Cook on a cauldron \\
Make the nation go forward \\
Must be twice \\
Support Jokowi \\
For 2 times \\
Tralalalalalala \\
Jokowi is a candidate \\
Amin is the running mate \\
Tralalalalalalala"
\end{tabular}

Political communication of polite leadership is one of the keys to success in leadership. The dimension of leader political communication is not only verbal. It is as stated (Riaz, 2010) Political communication includes visual representations such as clothing, make-up, hairstyles, logos, etc., so it is not only limited to verbal forms. Furthermore, Arumsari et al. (2017) express that politics is basically nothing but communicating. One of the political communication strategies of leadership that can be built is by using humor. 
2. Politico Pragmatic Power of Positive

\section{Politeness}

Politico-pragmatic power is the meaning that is implied behind an utterance, which can move someone to do something that is meant in the implied meaning. The politico pragmatic power found in the followers of Instagram account followers is as follows: the power to request; praise power; power supports; power effect; motivating power; and power suggest. The following table presents a classification chart of positive politico-pragmatic politeness in Jokowi's Instagram account.

Based on Figure 2 below, the power of politico pragmatic is the most dominant. It shows the speaker has many requests submitted to the speech partner. Requests submitted to speech partners include pleading to maintain health and pleading to become president in 2019-2024. This pleading strategy is a trait used by the people led by their leaders. Communities are socially under the coordination of their leaders (Barati, Tajrishi, \& Sajedi, 2012; H.J. Prayitno, Ngalim, Rohmadi, \& Riyanto, 2018). This strategy is important to be used as character education for children to their teachers. A positive politeness strategy that stems from an internal urge that respecting others is an awareness (Healy, 2018; K. H. Tan \& Farashaiyan, 2012). Illustration of the complete discussion is given through the following discussion.

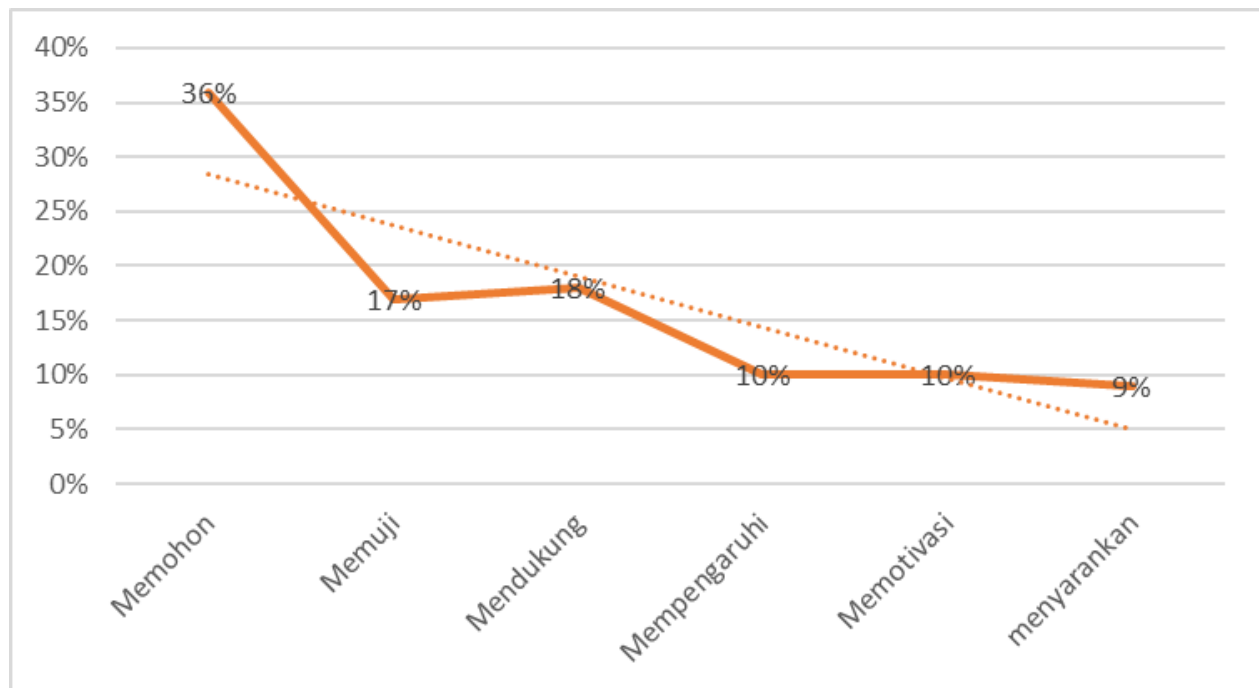

Figure 2. Taxonomy of Meaning of Politico pragmatic Power of Positive Politeness in Jokowi's Instagram Account Followers Comments

\section{a. Begging Power}

Politico pragmatic power of requesting is the strength of the message generated from Jokowi's Instagram account followers' comments for begging. Power begs in Jokowi's Instagram account comments used to invoke speech partners to maintain health and beg to become president. Slamet dan Suwarto (2013) state that the application form in- cludes directive speech acts. The following table 3 presents the power of begging.

\section{The Power of Begging to Maintain Health}

The power of begging to maintain health in terms of Jokowi's Instagram account is intended so that the speech partners maintain health. It is due to the work of the speech partner as a busy president. The following 
data shows the power begging to maintain health.

Speech in data (8) below is delivered by the owner of the Instagram account didijournal. The speech is a healthy political discourse; in the speech there is the power to beg for health. It can be seen in the speech Jaga kesehatan ya pak, dan kita sebagai rakyat Indonesia, tak henti mendoakan korban gempa dan Indonesia, dan tak lupa kami menyelipkan doa agar bapak diberikan kesehatan dan kekuatan (Take care of your health, sir, and we as the people of Indonesia, endlessly pray for the victims of the earthquake and Indonesia, and do not forget to pray for your health and strength).

Table 8. Politeness of Begging to Maintain Health

\begin{tabular}{l} 
Explicator \\
\hline J8] kaga kesehatan ya pak, dan kita sebagai \\
rakyat Indonesia, tak henti mendoakan \\
korban gempa dan Indonesia, dan tak \\
lupa kami menyelipkan doa agar bapak \\
diberikan kesehatan dan kekuatan. \\
(didijournal, 19-10-2018) \\
Take care of your health, sir, and we as \\
the people of Indonesia, endlessly pray \\
for the victims of the earthquake and \\
Indonesia, and do not forget we put in a \\
prayer for your health and strength.
\end{tabular}

The context of the speech above occurs because Mr. Jokowi uploaded his togetherness with world leaders in Bali to participate in IMF World Bank activities. Therefore, his busy schedule, following the activity that is so busy, the speaker asks the speech partner to take care of their health.

\section{The Power of Begging to Become President}

Table 9. Politeness of Begging to Become President

\begin{tabular}{|c|c|c|c|}
\hline & Explicator & Context & Meaning \\
\hline [9] & $\begin{array}{l}\text { Sehat selalu pak Jokowi biar bisa memimpin } \\
\text { Indonesia } 5 \text { tahun lagi. Indonesia sangat } \\
\text { membutuhkan pemimpin seperti bapak } \\
\text { (nawaty0, 7-10-2018) } \\
\text { Always be healthy, Mr. Jokowi so you can } \\
\text { lead Indonesia in } 5 \text { years. Indonesia really } \\
\text { needs a leader like you. }\end{array}$ & $\begin{array}{l}\text { Jokowi posted a post } \\
\text { regarding the opening of the } \\
2018 \text { Asian Para Games, at } \\
\text { the Bung Karno Main } \\
\text { Stadium with Bulan and } \\
\text { archery athlete Abdul Hamid. }\end{array}$ & $\begin{array}{l}\text { Begging to be } \\
\text { president }\end{array}$ \\
\hline
\end{tabular}

Speech in data (9) above is a political discourse of leadership. The speech above is powerless to ask the speech partner to become the president of Indonesia for 2019-
The second begging power in Jokowi's Instagram account followers' comments is to beg to be president. It was motivated by Jokowi's leadership which was considered good by the speakers. Thus, the speaker begs Jokowi to become president for the second period, namely the 2019-2024 period. The following is a helpless commentary requesting to become president.

Jokowi uploaded a post about with many world leaders who were present in Bali. Meaning Begging

Jokowi uploaded a togetherness with many
his leaders who were
world lesent in Bali.

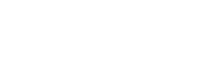


always, Mr. Jokowi so you can lead Indonesia in 5 years. Indonesia really needs a leader like you) intends to plead to the speech partner to become the second president of Indonesia 2019-2024.

The context of the speech is motivated because Jokowi uploaded his activities in the opening of the 2018 Asian Para Games. Asian Para Games is a sports party for people with disabilities. Based on this, speakers intend to plead for Jokowi to become president in the second period. It means that the speaker feels happy with Jokowi's leadership.

\section{b. Power of Praise}

The power of politico pragmatic praise is the power of the message generated from Jokowi's Instagram account followers' comments to praise Jokowi's achievements in leading Indonesia. Power of praise of Jokowi's Instagram account comments is used to compliment the speech partner because of the achievements he had made, especially when he became president. Kusno (2015) says that expressing praise is as a form of appreciation for others. The following comments are the power of praise.

Table 10. Politeness of Praise Power

\begin{tabular}{llll}
\hline \multicolumn{1}{c}{ Explicator } & \multicolumn{1}{c}{ Context } & Meaning \\
\hline [10] Cuma di jaman pak Jokowi Idonesia & $\begin{array}{l}\text { Jokowi uploaded the posting } \\
\text { prestasinya mendunia (arclim_cm, 8-11- }\end{array}$ & Praising \\
2018) & $\begin{array}{l}\text { at the Yuli Irawan's arrival } \\
\text { returning from the world } \\
\text { weightlifting championship in }\end{array}$ \\
$\begin{array}{l}\text { Only in the era of Mr. Jokowi, Indonesia's } \\
\text { achievements become worldwide }\end{array}$ & Turkmenistan.
\end{tabular}

Speech in data (10) above is a political discourse on sports. The speech above is delivered by the owner of the arclim_cm Instagram account. The utterances have the power of praise. It can be seen in the speech Cuma di jaman pak Jokowi Idonesia prestasinya mendunia (Only in the era of Mr. Jokowi, Indonesia's achievements become worldwide) the speaker of the speech intends to praise the achievements of the global sporting world. The sport's achievements were due to Jokowi's leadership. Based on this, the speaker intends to praise Jokowi.

The context of the speech was delivered because Jokowi uploaded the arrival of Eko Yuli Irawan at the Merdeka Palace, after returning from the world weightlifting championship in Turkmenistan. Eko Yuli Irawan is a weightlifting athlete, at the 2018 Asian Games event getting gold medalist. Based on this, the speakers praised the achievements of the nation's children worldwide; it is inseparable from the success of Jokowi's leadership in the field of sports. Jokowi also gave a good appreciation to the athletes who excel.

\section{Power of Supporting}

Supporting politico pragmatic power is the strength of the message generated from Jokowi's Instagram account followers' comments to support Jokowi's leadership in the second period, namely 2019-2024. Supporting power in Jokowi's Instagram account comments is used to support speech partners because the leadership can be said to be successful. The following are the supportive power comments.

The speech in data (11) is a religiouspolitical discourse. The utterances mentioned above have supporting power to support Jokowi's leadership for the 2019-2024 peri- 
od. It can be seen in the speech Selamat memperingati maulid nabi pak Jokowi. Sehat selalu Pak. Salam jempol 2 periode (Congratulations in commemorating the birthday of the Prophet, Mr Jokowi. Always healthy, sir. Thumbs greeting for 2 periods). The intention or the power of speech is supporting Jokowi's next leadership, which is to become president.

Table 11. Politeness of Suporting Power

\begin{tabular}{|c|c|c|c|}
\hline & Explicator & Context & Meaning \\
\hline \multirow[t]{2}{*}{ [11] } & $\begin{array}{l}\text { Selamat memperingati maulid nabi pak } \\
\text { Jokowi. Sehat selalu Pak. Salam jempol } \\
2 \text { periode (ryan_setiawan21, 20-11- } \\
2018 \text { ) }\end{array}$ & $\begin{array}{l}\text { Jokowi uploaded a post } \\
\text { regarding the anniversary of } \\
\text { the Prophet Muhammad's } \\
\text { birthday at the Bogor Palace. }\end{array}$ & Supporting \\
\hline & $\begin{array}{l}\text { Congratulations in commemorating the } \\
\text { birthday of the Prophet, Mr. Jokowi. } \\
\text { Always healthy, sir. Greetings thumb for } \\
2 \text { periods. }\end{array}$ & & \\
\hline
\end{tabular}

The context of the speech in the data above is due to Jokowi's activities in commemorating the birthday of the Prophet $\mathrm{Mu}$ hammad at the Bogor Palace. The speech has supporting power to support Jokowi's leadership for two periods. Speakers in the data give greetings to 2 periods. Based on that statement in the data above, it has supporting power.

\section{Power of Influence}

Politico-pragmatic power of influence is the strength of the message arising from the comments of Jokowi's Instagram account followers with the aim of the speech partner to choose Jokowi in the 2019 elections. The power of influence in Jokowi's Instagram account comments is used to influence the speech partners to choose Jokowi as president. Isa (2010) psychological and social factors will significantly affect an action, including speech acts that are directed towards the speech partner. The following are comments which have the power of influence.

Table 12. Politeness of Influence Power

\begin{tabular}{|c|c|c|c|}
\hline & Explicator & Context & Meaning \\
\hline$[12]$ & $\begin{array}{l}\text { Presiden joko widodo blusukan hari } \\
\text { minggu ke pasar anyar di Kota } \\
\text { Tanggerang, Banten, ini pasar } \\
\text { tradisional kedua yang saya kunjungi } \\
\text { pekan ini. Coblos no } 1 \text { saja Jokowi- } \\
\text { Ma'ruf Amin } 2019 \text { Indonesia semakin } \\
\text { maju (wawan_jiswan1, 20-10-2018) } \\
\text { President Joko Widodo was wandering } \\
\text { around on Sunday to pasar anyar (the } \\
\text { brand-new market) in Tangerang City, } \\
\text { Banten. It is the second traditional } \\
\text { market that I visited this week. Vote } \\
\text { only number one Jokowi-Ma'ruf Amin. } \\
\text { In } 2019 \text { Indonesia is getting ahead. }\end{array}$ & $\begin{array}{l}\text { Jokowi memposting kegiatan } \\
\text { setiap pagi, yakni memantau } \\
\text { perkembangan harga bahan } \\
\text { pokok dan pangan. } \\
\text { Jokowi posted an activity } \\
\text { every morning, which was } \\
\text { monitoring the development } \\
\text { of prices of staples and food. }\end{array}$ & Influencing \\
\hline
\end{tabular}


Speech in data (12) is an economic political discourse. The utterance was delivered by the Instagram account voter of $w \boldsymbol{a}$ wan_jiswan1. The speech has the power of influence. It is seen from the utterances Presiden joko widodo blusukan hari minggu ke pasar anyar di Kota Tanggerang, Banten, ini pasar tradisional kedua yang saya kunjungi pekan ini. Coblos no 1 saja Jokowi-Ma'ruf Amin 2019 Indonesia semakin maju (President Joko Widodo was wandering around on Sunday to pasar anyar (the brand-new market) in Tangerang City, Banten. It is the second traditional market that I visited this week. Vote only number one Jokowi-Ma'ruf Amin. In 2019 Indonesia is getting ahead). The speech begins with Jokowi's wandering around activities every Sunday, but in the end, the speaker influences the speech partner to elect Jokowi as president in the 20192024 period.

The context of the speech in the data above is because Jokowi posted activities every morning, which is monitoring the price of staples and food. It was done to control the prices of basic needs and food because previously it was rumored that prices of basic needs and food had increased. Therefore, the speaker influences the speech partner by saying that Jokowi every Sunday bludges on the market to monitor the price of basic needs and food.

\section{Power of Motivating}

Motivating of politico pragmatic power is the power of the message generated from Jokowi's Instagram account followers' comments to motivate the speech partners to work enthusiastically despite criticism, scorn, slander and so on. Motivating power in Jokowi's Instagram account comments is used to motivate Jokowi in carrying out state duties, even though he is being criticized that he must remain enthusiastic. The following comments are powerless influences.

Speech on data (13) below was conveyed by the owner of the Instagram account ibrahimnurhadi. The speech has power of motivating the speech partner. It can be seen in the speech Indonesia bukan dengerin suara netizen. Tetapi dengerin suara hati rakyat. Semangat terus pakdeh. Doa saya sebagai muslim agar selalu siberikan pemimpin yang baik (Indonesia is not listening to the voice of netizens. But listen to the conscience of the people. Keep up the spirit, Uncle. My prayer as a Muslim is to always provide a good leader). The purpose of the speech is to give motivation to speech partners in carrying out state duties.

Table 13. Politeness of Motivating Power

Explicator
[13]


The context of the speech is that Jokowi uploaded a post regarding the opening of the 2018 Asian Para Games, at the Bung Karno Main Stadium with Bulan and archery athlete Abdul Hamid. The convening of the Asian Para Games in Indonesia some like and some others do not like. Therefore, the speaker gives motivation to the speech partner that in carrying out the tasks of the state there must be some who mock and some support.

\section{Power of Suggesting}

Politico-pragmatic power of suggestion is the strength of the message generated from Jokowi's Instagram account followers comments with the aim that the speech partner pays attention to the price of food commodi- ties. Purnami (2018) states the form of advice can be in the form of instructions or advice orders. Suggestions are communication strategies of sociopragmatic communication to shorten the closeness of social distance between speakers and speech partners. Suggestions that positive value politeness is suggestions that are free from the interests that give advice. This advice is driven by internal motivation so that the advice given becomes better. Suggestions are a form of scholarship and social attention (Gertsog, Danilova, Korneev, Savchenkov, \& Uvarina, 2017; Robertson, Hepburn, McLauchlan, \& Walker, 2017). The power of suggesting in Jokowi's Instagram account comments the form of a suggestion command. The following comment has the power of suggestion.

Table 14. Politeness of Suggesting Power

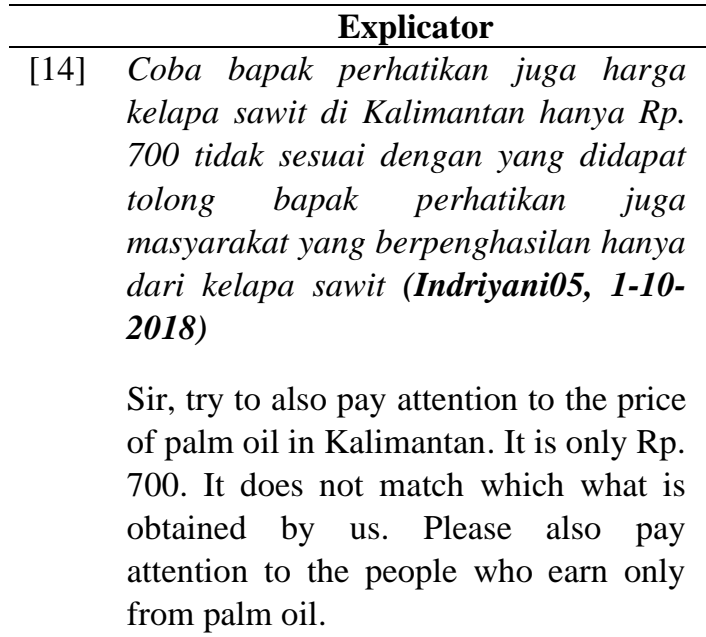

Context

Meaning

Jokowi posted an activity Suggesting

every morning, which was monitoring the development of prices of staples and food.

Speech in data (14) above is an economic-political discourse. The utterances are utterances which have the power of suggestion. It can be seen in the utterances delivered by Instagram account owners Indriyani05, Coba bapak perhatikan juga harga kelapa sawit di Kalimantan hanya Rp. 700 tidak sesuai dengan yang didapat tolong bapak perhatikan juga masyarakat yang berpenghasilan hanya dari kelapa sawit (Sir, please pay attention also to the price of palm oil in Kalimantan. It is only Rp. 700. It does not match which what is obtained by us. Please also pay attention to the people who earn only from palm oil). The purpose of the speech is to suggest the speech partner pay attention to the price of oil and pay attention to people who only earn from oil palm.

The context of the speech is Jokowi posts activities every morning to monitor the development of prices of staples and food. Speakers who practice as palm oil farmers 
advise so that the speech partners monitor not only the price of food and basic needs such as vegetables and meat but also the price of oil palm which is only seven hundred rupiahs. In addition, speakers also provide advice to speech partners to pay attention to communities that only earn income from oil palm.

\section{Conclusion}

The rule that results from this study is that a form of positive politeness that can be used by followers to comment on the Instagram account of the highest official in a country is by giving attention to the speech partner. The integration of attention and leadership becomes an important foundation in the sustainability of public leadership. Politopragmatic politeness of positive politeness comments of Instagram account followers both aimed at the power of request, the power of praise, the power of support, the power of influence, the power of motivation, and the power of suggestion to be the glue of two persons between the leader and the person he leads. It shows Instagram account followers have an optimistic attitude towards Jokowi's leadership. Jokowi's Instagram account followers have a sense of trust in the success of Jokowi's leadership. The attitude of optimism and a sense of trust between two entities, namely the leader and the leader they lead are the values of the main character education in the era of disruption of education as it is today.

\section{References}

Abbas, N. F. (2013). Positive Politeness \&amp; Social Harmony in Literary Discourse. International Journal of Applied Linguistics \& English Literature, 2(3), 186-195. https://doi.org/10.7575/aiac.ijalel.v.2n.3 p.186

Abdullah, I. (2017). Di Bawah BayangBayang Media: Kodifikasi, Divergensi, dan Kooptasi Agama di Era Internet. Sabda, 12(2), 116-121. https://doi.org/https://doi.org/10.14710/ sabda.12.2.116-121

Adams, M. (2009). Power, Politeness, and the Pragmatics of Nicknames. A Journal of Onomastics, 57(2), 81-91. https://doi.org/10.1179/175622709x436 369

Ahmed, W. K., \& Maros, M. (2017). Using hedges as relational work by Arab EFL students in student-supervisor consultations. GEMA Online Journal of Language Studies, 17(1), 89-105. https://doi.org/10.17576/gema-20171701-06

Aisyah, A. R. (2014). Teaching and Learning At Personality Development Unit in the. International Journal of Education Research, 2(10), 203-214.

Arumsari, N., Septiana, W. E., Luthfi, M., \& Rizki, N. K. A. (2017). Komunikasi Politik Kepala Desa dalam Mendorong Inovasi Pembangunan Desa: Studi Kasus Tiga Desa di Lereng Gunung Ungaran, Jawa Tengah. Politik Indonesia: Indonesia Political Science Review, 2(1), 86-99.

Aziz, A. A. (2017). Agreement Strategies Among Malaysian Chinese Speakers of English. 3L: The Southeast Asian Journal of English Language Studies, 23(1), $168-189$. https://doi.org/http://doi.org/10.17576/3 L-2017-2301-12 Agreement

Barati, H., Tajrishi, P., \& Sajedi, F. (2012). The effect of social skills training on socialization skills in children with Down syndrome. Iranian Rehabilitation Journal, 10(15), 35-38. Retrieved from https://irj.uswr.ac.ir/article-1-240-en.pdf Cisco, J. (2016). A Case Study of University Honors Students in Humanities 
Through a Disciplinary Literacy Lens. Literacy Research and Instruction, 55(1), $1-23$. https://doi.org/10.1080/19388071.2015. 1063742

Darwis, Y., Sciences, P., \& Sumatra, W. (2013). Communication Media ( ECommerce ) As a Supporting Factor in Indonesia' S Fashion Industry in the. The International Journal of Organizational Innovation, 5(January).

Dynel, M. (2016). Conceptualizing Conversational Humour as (im)politeness : The Case of Film Talk. Journal of Politeness Research 2016; 12(1), 117-147. https://doi.org/10.1515/pr-2015-0023

Dynel, M., \& Poppi, F. I. M. (2019). Risum teneatis , amici? *: The sociopragmatics of RoastMe humour. Journal of Pragmatics, 139, 1-21. https://doi.org/10.1016/j.pragma.2018.1 0.010

Fauziati, E. (2016). Applied Linguistics Principle of Foreign Language Teaching, Learning, and Researching. Surakarta: Era Pustaka Utama.

Fitriani, R. S. (2015). Kesantunan Tuturan Imperatif Siswa SMK Muhammadiyah 2 Bandung: Kajian Pragmatik. Ranah: Jurnal Kajian Bahasa, 4(1), 34-46. https://doi.org/https://doi.org/10.26499/r nh.v4i1.23

Gertsog, G. A., Danilova, V. V., Korneev, D. N., Savchenkov, A. V., \& Uvarina, N. V. (2017). Professional identity for successful adaptation of students - A participative approach. Rupkatha Journal on Interdisciplinary Studies in Humanities, 9(1), 301-311. https://doi.org/10.21659/rupkatha.v9n1. 30

H.K, T., M, L, T., \& S.K, T. (2014). Beyond ' Greeting' and ' Thanking ': Politeness in Job Interviews. 3L: The Southeast Asian Journal of English Language
Studies, 22(3), 171-184.

Healy, M. (2018). Belonging, Social Cohesion and Fundamental British Values. British Journal of Educational Studies, $\quad$ 00(00), 1-16. https://doi.org/10.1080/00071005.2018. 1506091

Herniti, E., Budiman, A., \& Kusumawati, A. A. (2016). Kesantunan Berbahasa dalam Dakwah Multikultural. Adabiyyat, $\quad X V(1), \quad 36-62$. https://doi.org/https://doi.org/10.14421/ ajbs.2016.15103

Isa, A. A. (2010). Tutur Sapa Bahasa Inggris-Amerika dalam Aspek Sosiolinguistis, Pragmatis, dan Psikologis. Widyaparwa, 38(1), 45-58. https://doi.org/ttps://doi.org/10.26499/w dprw.v38i1.9

Jahdiah. (2018). Kesantunan Tindak Tutur Bamamai dalam Bahasa Banjar: Berdasarkan Skala Kesantunan Leech. Ranah: Jurnal Kajian Bahasa, 7(2), 164-179.

https://doi.org/https://doi.org/10.26499/r nh.v7i2.530

Jauhari, E. (2018). Alat-alat Kesantunan Kritik dalam Masyarakat Jawa Surabaya: Kajian Pragmatik. Mozaik Humaniora, 18(2), 167-177. https://doi.org/http://dx.doi.org/10.2047 3/mh.v18i2.10931

Jauhari, E., \& Susanto, D. (2014). Realisasi Kesantunan Positif dalam Masyarakat Etnik Tionghoa di Surakarta. In Seminar Nsional Prasasti (Pragmatik dan Linguistik) (pp. 61-72). https://doi.org/http://dx.doi.org/10.2096 1/pras.v0i0.524

Koussouhon, L. A., \& Dossoumou, A. M. (2015). Political and Ideological Commitments: A Systemic Functional Linguistic and Critical Discourse Analysis of President Buhari's Inaugural Speech. International Journal of Linguistics and Communication, 
$3(2)$, 24-34.

https://doi.org/10.15640/ijlc.v3n2a3

Kusno, A. (2015). Pematuhan dan Pelanggaran Prinsip Kesopanan Serta Fungsinya dalam Wacana Terkait Usulan Dana Aspirasi DPR di Rubrik Politik Kompasiana. Widyaparwa, 43(1), 65-78. https://doi.org/https://doi.org/10.26499/ wdprw.v43i1.106

Kusno, A., \& Rahman, A. (2016). BentukBentuk Pelanggaran Prinsip Kesopanan dalam Ceramah Keagamaan. LiNGUA: Jurnal Ilmu Bahasa Dan Sastra, 11(2), 103-115.

https://doi.org/10.18860/ling.v11i2.350 2

Leech, G. (2014). The Pragmatics of Politness. America: Oxford University Press.

Leiliyanti, E., Diyantari, \& Irawati. (2017). Transcoding Wacana Konstruksi dan Kontestasi Citra Jokowi dan Prabowo dalam Media Sosial pada Masa Kampanye Pilpres 2014. Mozaik Humaniora, 17(2), 192-213. https://doi.org/http://dx.doi.org/10.2047 3/mh.v17i2.5507

Mahsun, M. (2014). Metode Penelitian Bahasa: Tahapan, Strategi, dan Tekniknya. Jakarta: Raja Grafindo Persada.

Mansor, N. S., Mamat, R., Omar, R. C., \& Ghazali, A. H. A. (2014). Ketidaksantunan Bahasa sebagai Strategi Pujukan dalam Iklan Berbahasa Sepanyol. GEMA Online Journal of Language Studies, 14(3), 207-223. https://doi.org/10.17576/GEMA-20141403-13

Maros, M., \& Rosli, L. (2017). Politeness strategies in twitter updates of female english language studies Malaysian undergraduates. $3 \mathrm{~L}$ : Language, Linguistics, Literature, 23(1), 132-149. https://doi.org/10.17576/3L-2017-2301-
10

Najeeb, Z. M., Maros, M., \& Nor, N. F. M. (2012). Politeness in e-mails of Arab students in Malaysia. GEMA Online Journal of Language Studies. https://doi.org/10.1007/978-0-38735577-1_2

Noor, K. U., \& Prayitno, H. J. (2016). Pergeseran Kesantunan Positif Siswa Kelas IX MTsN 1 Surakarta Berlatar Belakang Budaya Jawa. Kajian Linguistik Dan Sastra, 1(1), 17-24.

Öztürk, A., Varoğlu, M. A., \& Varoğlu, D. (2017). A Critical Review of Implicit Leadership Theory on the Validity of Organizational Actor-National Culture Fitness. International Journal of Organizational Leadership, 6(4), 456469.

https://doi.org/http://dx.doi.org/10.1923 6/IJOL.2017.04.03

Prasetyo, D. (2014). Persepsi Masyarakat DKI Jakarta Terhadap Figur dan Komunikasi Politik Basuki Tjahaja Purnama (Ahok). POLITIKA, 5(2), 113. https://doi.org/10.5591/978-157735-516-8/IJCAI11-020

Prayitno, H.J., Ngalim, A., \& Jamaluddin, N. (2018). Pergeseran Realisasi Tindak Kesantunan Direktif Mereduksi Nilai Kesantunan Positif dan Karakter di Kalangan Peserta Didik. Jurnal Bahastra, XXXVIII(2).

Prayitno, H.J., Ngalim, A., Rohmadi, M., \& Riyanto, U. (2018). Strategies of Refusal Speech Act by Javanese Culture-based Students at Darul Ihsan Muhammadiyah Islamic Boarding School Sragen Indonesia. EduLearn Journal, 12(3), 520-528. https://doi.org/10.11591/edulearn.v12i3. 9300

Prayitno, Harun Joko. (2015). Tindak Kesantunan Berbahasa dalam Dialektika Pembelajaran Pragmatik: Berdaya, Berorientasi, dan Berstrategi 
Kesantunan Positif. Seminar Nasional PRASASTI "Kajian Pragmatik Dalam Berbagai Bidang:, (April), 24-35.

Prayitno, Harun Joko, Ngalim, A., Sutopo, A., Rohmadi, M., \& Yuniawan, T. (2018). Power, Orientation, And Strategy Of Positive Politeness Used By Children At The Age Of Elementary School With Javanese Cultural Background. Humanus: Jurnal Ilmiah Ilтu-Ilти Humaniora, 17(2), 164-173. https://doi.org/10.24036/humanus.v17i2 .101371

Purnami, W. H. (2018). Ranah Pesan pada Papan Petunjuk di Objek Wiasata Daerah Istimewa Yogyakarta. Widyaparwa, 46(2), 157-167. https://doi.org/https://doi.org/10.26499/ wdprw.v46i2.205

Rachmiatie, A., Hasbiansyah, O., Khotimah, E., \& Ahmadi, D. (2019). Strategi Komunikasi Politik dan Budaya Transparansi Partai Politik. Mimbar, 29(2), 123-132. https://doi.org/https://doi.org/10.29313/ mimbar.v29i2.384

Riauan, M. A. . I., \& Shasrini, T. (2017). Dampak Komunikasi Terapeutik Terhadap Citra Pelayanan Kessehatan: Studi Kasus di Rumah Sakit Umum Daerah Arifin Achmad Pekanbaru. THE MESSENGER, 9(1), 31-43.

Riaz, S. (2010). Effects of New Media Technologies on Political Communication. Journal of Political Studies, 1(2), 161-173.

Robertson, L., Hepburn, L., McLauchlan, A., \& Walker, J. (2017). The humanities in the primary school-where are we and in which direction should we be heading? A perspective from Scotland. Education 3-13, 45(3), 320-331. https://doi.org/10.1080/03004279.2017. 1296920

Setijowati, A. (2018). Pola Antenatal Care dan Health Seeking Behavior Ibu Hamil
Suku Mbojo, Bima, Nusa Tenggara Barat. Mozaik Humaniora, 18(1), 3349.

https://doi.org/http://dx.doi.org/10.2047 3/mh.v18i1.9881

Singh, R., \& Chakrabarti, R. (2017). From the inferior other to the becoming being: A reading of dracula from Haddon's frame. Rupkatha Journal on Interdisciplinary Studies in Humanities, 9(4), 74-81. https://doi.org/10.21659/rupkatha.v9n4. 08

Slamet, S. ., \& Suwarto, W. . (2013). Bnetuk Tindak Tutur Direktif Kesantunan Berbahasa Mahasiswa PGSD di Lingkungan Jawa Tengah: Tinjauan Sosiopragmatik. Widyaparwa, 4l(1), 41-52.

https://doi.org/https://doi.org/10.26499/ wdprw.v41i1.65

Sukarno. (2015). Politeness Strategies in Responding to Compliments in Javanese. Indonesian Journal of Applied Linguistics, 4(2), 91-101. https://doi.org/http://dx.doi.org/10.1750 9/ijal.v4i2.686

Sukarno. (2018). Politeness Strategies, Linguistic Markers and Social Contexts in Delivering Requests in Javanese. Indonesian Journal of Applied Linguistics, 7(3), 659-667. https://doi.org/10.17509/ijal.v7i3.9816

Tamrin. (2014). Kesantunan Berbahasa Bugis pada Masyarakat Bugis di Kabupaten Sinjai Provinsi Sulawesi Selatan. Multilingual, 13(2), 208-218.

Tan, H. K., Teoh, M. L., \& Tan, S. K. (2016). Beyond "greeting" and "thanking": Politeness in job interviews. 3L: Language, Linguistics, Literature, 22(3), 171-184.

Tan, K. H., \& Farashaiyan, A. (2012). The effectiveness of teaching formulaic politeness strategies in making request to undergraduates in an ESL classroom. 
Asian Social Science.

https://doi.org/10.5539/ass.v8n15p189

Tojo, H., \& Takagi, A. (2017). Trends in Qualitative Research in Three Major Language Teaching and Learning Journals, 2006-2015. International Journal of English Language Teaching, 4(1), 37. https://doi.org/10.5430/ijelt.v4n1p37

Ulum, D. E. L., \& Kusmanto, H. (2018). Disfemia pada Komentar Akun Instagram Mimi.Peri. In Seminar Kajian Bahasa, Sastra, dan Pengajarannya V (pp. 232-237).

Yayuk, R. (2016). Strategi Tindak Tutur Imperatif Bahasa Banjar. Metalingua, 14(2), 225-231. https://doi.org/http://dx.doi.org/10.2649 9/metalingua.v14i2.198

Yuliana, R., Rohmadi, M., \& Raheni, S. (2013). Daya Pragmatik Tindak Tutur Guru dalam pembelajaran Bahasa Indonesia Pada Siswa Sekolah Menengah Pertama. BASASTRA Jurnal Penelitian Bahasa, Sastra Indonesia Dan Pengajarannya, 2(1), 1-14.

Zurqoni, Z., Retnawati, H., Apino, E., \& Anazifa, R. D. (2019). Impact of Character Education Implementation: a Goal-Free Evaluation. Problems of Education in the 21st Century, 76(6), 881-899.

https://doi.org/10.33225/pec/18.76.88 1. 